\title{
Review
}

\section{The sacredness of the person: A new genealogy of human rights}

\author{
Hans Joas \\ Georgetown University Press, Washington DC, 2013, xi+217pp., \\ ISBN: 978-1589019690
}

Contemporary Political Theory (2016) 15, e41-e44. doi:10.1057/cpt.2015.48;

published online 22 September 2015

Hans Joas ranks among the most distinguished European social theorists of the past two or three decades. Deeply grounded in the classical sociological tradition, his work has contributed to reshaping conceptual debates on action and value theory (Joas, 1996, 2000) and it has also reflected on war as a major pillar of modern society (Joas, 2003). In this new book, Joas brings together these strands of his work in order to develop a new genealogy of human rights that centres on the idea of the sacredness of the person.

Quite rightly, Joas is troubled by the problem of how we can normatively justify human rights (p. 1) and builds an 'affirmative genealogy of the universalism of values' (p. 3) as a third way between purely negative critiques that end up in relativism and exclusively normative arguments, which he finds self-defeating. He seeks to account for the emergence of human rights as a secular discourse that stands in continuity with, rather than in opposition to, Christian traditions (p. 4): human life is endowed with a particular kind of dignity that allows us to speak about the sacredness of the person (p. 5).

Chapter 1 begins by offering a stylised historical narrative with which to redress the anti-religious bias of conventional accounts of human rights; in particular, he looks at the Christian motifs in the wars of American independence and explains their influence in the rise of modern human rights (pp. 21-28). Chapter 2 then links early developments of the idea of the sacredness of the person to the prohibition of torture as a legitimate form of punishment (p. 37), and in a wonderful turn he contends that, pace Foucault, modern penal systems are spaces for inclusion: '[a]s paradoxical as it sounds, confinement in asylums may be regarded as a first, albeit inconsistent step towards the integration of the lunatic into the human species ... disciplining is only an inadequate attempt to facilitate inclusion' (p. 48). Chapter 3 concentrates on the role of such traumatic historical experiences as genocide, racism and colonialism in creating a positive motivational attachment to universal values. Here the theoretical 
counterpoint is offered by Jeffrey Alexander, whose work is criticised as excessively constructivist quite rightly, Joas emphasises the importance of clearly distinguishing between cultural trauma as a form of public discourse and personal experiences of trauma that by definition are hard to fully articulate discursively (pp. 76-85). I will leave Chapter 4 for my discussion below.

Chapter 5 concentrates on the idea of the soul as a counterbalance to exclusively sociological ideas of the self (p. 153). Joas builds here on insights by William James and Talcott Parsons, and contends that questions of love, creation, dignity and gift all point to a sense of transcendence that acts as precondition for ideas of human dignity and eventually for human rights themselves. The argument is that while human rights cannot be reduced to any particular religious or philosophical tradition (pp. 140-141), we cannot truly think human rights without some religious underpinnings: human dignity is transcendent vis-à-vis humanity itself. Finally Chapter 6 deals directly with Parsons' notion of value generalisation, and Joas shows there that the drafting of the 1948 Universal Declaration of Human Rights was itself a complex process of negotiation between different sociocultural traditions, political interests and religious worldviews. As they explicitly avoided questions of 'philosophical justification' (p. 187), those who participated in the drafting of the declaration were interested in producing a nonbinding legal text that could offer normative guidance in the reconstruction of the international order after the war.

This is an extremely important book because it dares to raise a novel approach to what to my mind remains the key normative demand of modern times: the difficult yet essential question of universal values. Although I do not share its religious convictions, and below I will reflect on that question, the book must be praised in this fundamental sense. Let me now concentrate on two issues that I think deserve further discussion.

My first comment has to do with the tradition of modern natural law. Its role in the formation of the normative vocabulary of modernity is raised several times throughout the book, yet Joas never considers natural law theory in its own right (pp. 3, 18, 20, 25-27, 54, 71-72, 141, 181). This is to be expected from a narrow sociological perspective that simply rejects any possible debt to modern natural law theory, but Joas' book is anything but narrow in this sense. Maybe here Joas' commitment to pragmatism prevents him from offering a more nuanced account of modern natural law theory, or maybe this is to do with an ideological context in which the term 'natural law' has become so strongly associated with extreme Christian conservatism that he does not think it can be rescued. This neglect remains problematic on at least three grounds.

First, this goes against one key substantive insight that comes out of Joas' main hero in this project. The reconfiguration of natural law arguments in modern times is central to Troeltsch's (2005) own contribution to the early institutionalisation of German sociology. Second, this matters because of the prima facie case that modern human rights offer a rearticulation of secular and religious natural law arguments in 
relation to the ever-changing conditions of modern times - not least because this is how the French and American revolutionaries saw their own philosophy and politics at the time (Habermas, 1973). Given that Joas himself acknowledges how laborious it is to work out an argument that draws on, but does not depend on, one's religious beliefs (pp. 140-143, 155-158), then a broad conception of modern natural law could have allowed for a smoother account for the religious continuities and discontinuities in the emergence of modern human rights. Finally, it is precisely this broader conception of modern natural law theory and its influence in the rise of modern social theory that we still need to account for: most if not all the main issues that are central to this book - sovereignty and social inclusion, empathy and moral decentring, dignity and justice and of course moral universalism itself - are also central to modern natural law (Chernilo, 2013; Chernilo and Fine, 2013). My point is not at all that we go back to natural law as the one tradition that can solve all normative challenges, but rather that Joas' book demonstrates that those who have a genuine interest in normative debates may need to reassess modern natural law/ right as an ample tradition that has systematically looked for the justification of universalistic values.

My second comment refers to Joas' theoretical approach as developed in Chapter 4 . There he introduces the suggestive notion of 'affirmative genealogy' as a way of transcending the motivational and justificatory deficits of normative approaches (as best represented in Kant and Habermas) and the relativistic overtones of the genealogical approaches of Nietzsche and Foucault (pp. 97-98). My own theoretical position is closer to the normative end, so it is not surprising that I disagree with some aspects of his interpretation of, say, Kant: the historical trends that Joas mentions as expressions of a nascent human rights discourse (global solidarity, trade, transnational organisations, pp. 90-92) resemble very closely indeed Kant's arguments in his Perpetual Peace essays.

But the substantive issue is not one of textual interpretation, of course. Being in favour of Joas' defence of a universalistic morality, I am however troubled by his defeatism with regard to the question of the possibility of rational justification of values. Here he builds on his previous interest in overcoming too strong a separation between 'genesis' and 'validity', or between 'construction' and 'discovery' of values (pp. 2-3), and this is now explicitly articulated in relation to personal religious beliefs: it is 'impossible' to fully appreciate the insights that come out Troelsch's work if we lack his 'sensitivity to the religious dimension' (p. 100). This, however, makes his wider claims harder to make: '[n]one of my remarks on life as a gift - or those on the concept of the soul - constitutes proof or an attempt to prove that we must believe in immortality and a creator. In the spirit of Pragmatism, my aim was merely to demonstrate that such a belief is not antithetical to reason' (p. 170). Differently put, the argumentation now relies on specific religious propositions whose very appeal lies in that they are particularly refractory vis-à-vis rational discussion: they are, simultaneously, deeply questionable to some and wholly 
unquestionable to others, and we find a whole array of different positions within each side. Joas forces himself to lower the standard of proof and becomes satisfied with propositions that cannot rationally be denied: 'we cannot rule out scientifically the possibility that our experiences of self-transcendence represent a genuine encounter with something transcendent' (p. 155, my italics).

From a sociological perspective it is difficult to see why, if Kantian morality was assessed as too restrictive and lacking in motivational purchase, then religious experiences or beliefs are to offer an improvement on similar challenges. If anything, Joas' reference to the origin of universalist values in the Axial Age (p. 176) points precisely to the strongest claim that there are some deep anthropological structures in our shared membership to the species that, beyond cultural and religious traditions, do speak of our human ability for self-transcendence. Joas' own argument on the process of generalisation of values speaks of a real process that makes it increasingly possible to offer a universalistic moral standpoint - even if asymptotically and provisionally.

\section{References}

Chernilo, D. (2013) The Natural Law Foundations of Modern Social Theory. A Quest for Universalism. Cambridge: Cambridge University Press.

Chernilo, D. and Fine, R. (2013) Introduction to the special issue on social theory and natural law. Journal of Classical Sociology 13(2): 191-196.

Habermas, J. (ed.) (1973) Natural law and revolution. In: Theory and Practice. Cambridge: Polity Press. Joas, H. (1996) The Creativity of Action. Cambridge: Polity Press.

Joas, H. (2000) The Genesis of Values. Cambridge: Polity Press.

Joas, H. (2003) War in Modernity. Cambridge: Polity Press.

Troeltsch, E. (2005) Stoic-Christian natural law and modern profane natural law. In: C. Adair-Toteff (ed.) Sociological beginnings. The First Conference of the German Society for Sociology. Liverpool, UK: Liverpool University Press.

Daniel Chernilo Loughborough University, Loughborough LE11 3TU, UK d.chernilo@lboro.ac.uk 